\title{
TRANSACTION COSTS AND THE NORMATIVE ELEMENTS OF THE PUBLIC CHOICE MODEL: AN APPLICATION TO CONSTITUTIONAL THEORY
}

\author{
Jonathan R. Macey*
}

Tto

$\mathrm{N}$ the wake of the Coase Theorem, ${ }^{1}$ transaction costs have come to play the pivotal role in economic discourse as it relates to legal issues. The Coase Theorem posits that, absent transaction costs, the efficient outcome will occur regardless of the choice of legal rule. ${ }^{2}$ In a wide variety of contexts, therefore, the quest to formulate efficient rules focuses on the nature of the transaction costs that hamper the parties' ability to contract effectively among themselves. This essay presents a model of the role that transaction costs play in the economic theory of legislation. ${ }^{3}$ By emphasizing the role of transaction costs in the "public choice" model, this exercise seeks to develop a normative argument about how consti-

* Professor of Law, Cornell University. A.B., Harvard University, 1977; J.D., Yale Law School, 1982. I am grateful for comments received at faculty workshops at Cornell Law School and the Center for Study of Public Choice at George Mason University, and during conversations with James M. Buchanan, William N. Eskridge, Jr., David B. Lyons, William T. Mayton, Dale A. Oesterle, Russell K. Osgood, and Steven H. Shiffrin. Robert McDonough, Cornell Law School '89, provided valuable research assistance.

1 Coase, The Problem of Social Cost, 3 J.L. \& Econ. 1 (1960).

2 This succinct formulation of the Coase Theorem is taken from A. Pohinsky, An Introduction to Law and Economics 12 (1983). For a useful and accessible discussion of the Coase Theorem, see id. at 11-13.

3 The economic approach to legislation applies standard principles of microeconomics to the provision of legislative protections. The development of a positive economic theory of legislation can be traced to J. Buchanan \& G. Tullock, The Calculus of Consent (1962), and Stigler, The Theory of Economic Regulation, 2 Bell J. Econ. \& Mgmt. Sci. 3 (1971). For extensions of the theory, see Becker, A Theory of Competition Among Pressure Groups for Pohtical Influence, 98 Q.J. Econ. 371 (1983); Peltzman, Toward a More General Theory of Regulation, 19 J.L. \& Econ. 211 (1976).

The economic theory of legislation is sometimes referred to as "public choice" theory. Public choice theory originated in the literature of game theory and provides tbe theoretical foundation for some of the insights of the economic theory of legislation. Professor Robert Tollison's review essay in this Symposium provides a useful description of both the current state of the literature on the economic theory of legislation and the more theoretical literature in the field of public choice. See Tollison, Public Choice and Legislation, 74 Va. L. Rev. 339 (1988). 
tutional rules in a "rent-seeking" society can increase societal wealth and improve the quality of a representative democracy.

An important goal of a well-developed legal system is to promulgate rules that reduce the transaction costs facing privately contracting parties. ${ }^{5}$ Mutual agreements reached by privately contracting parties work to the benefit of both parties. Therefore, to the extent that the legal system can facilitate these transactions by reducing their costs, everyone is made better off. By way of contrast, another important goal of a legal system that desires to promote social stability and social welfare is to increase the transaction costs facing parties who seek enactment of legislation that would employ the machinery of the state to effect coercive wealth transfers from one group to another. Even the possibility of such transfers reduces the wealth of society as a whole, as people are driven to consume resources to block such transfers. ${ }^{6}$

Part I of this Article presents both a brief description of the economic theory of legislation and an examination of its normative implications. The most important normative implication is that the use of governmental regulation to achieve wealth transfers imposes significant costs on society by impeding the process through which market forces create wealth. Unfortunately, however, it is extremely difficult to distinguish between those governmental activities that involve "amorally redistributive" rent-seeking (and therefore should be prohibited) and those that represent wealthincreasing "public interest" governmental activities (and therefore

\footnotetext{
- Rent-seeking refers to the attempt to obtain economic rents (i.e., rates of return on the use of an economic asset in excess of the market rate) through governmental intervention in the market. An example of rent-seeking is a firm's attempt to secure government-granted monopolies. Such monopolies allow a firm to increase its prices ahove competitive levels. The resulting profits represent economic rents from government regulation.

- Goetz \& Scott, The Limits of Expanded Choice: An Analysis of the Interactions Between Express and Implied Contract Terms, 73 Calif. L. Rev. 261, 266 (1985).

B This Article embraces the assumption that wealth creation and wealth transfers are mutually exclusive. I do not, however, mean to suggest that wealth transfers cannot enhance overall societal utility.

"The phrase "amorally redistributive" is Judge Posner's. See Posner, Economics, Politics, and the Reading of Statutes and the Constitution, 49 U. Chi. L. Rev. 263, 268 (1982).

${ }^{8}$ In addition to serving as a forum for rent-seeking activity, the government also performs important public interest functions, such as providing public goods (e.g., national defense); overcoming free-rider problems that prevent private parties from reaching mutually advantageous agreements (which is, for example, the ostensible purpose of environmental laws); and providing a responsible yet coercive enforcement mechanism for privately negotiated
} 
should be encouraged). For example, though laws that transfer wealth from one group to another are perhaps the classic example of rent-seeking legislation, ${ }^{9}$ such statutes also may be passed to solve the free-rider problems that thwart private efforts to reach the level of transfers that the transferors would prefer. ${ }^{10}$ Thus, the benefit of distinguishing interest group legislation from public interest legislation often will not be worth the cost.

Part II examines the current status of public choice scholarship in light of the normative principles developed in Part I. Scholarly opinion differs widely on the positive and normative implications of public choice theory, and this Part explores those implications. In the application of normative principles, transaction costs play the pivotal role in the economic theory of legislation. The role that transaction costs play in constitutional theory is of particular interest.

Two possible constitutional strategies can control the temptation of elected officials to sacrifice principle for partisanship in the course of daily political life. The first is to design a constitutional system that establishes incentives for politicians to behave in the public interest. Unfortunately, due to the lack of an effective measure of individual marginal performance upon which to base an incentive system for politicians, incentive-based constitutional systems do not hold much promise as a means to control the behavior of elected officials.

contracts. For essays on the "public interest" role of government, see W. Baumol, Welfare, Economics and the Theory of the State (2d ed. 1965); A. Pigou, The Economics of Welfare (4th ed. 1932). In economic terms, the public interest functions of government are to intervene in the market economy to correct market failures or distributional shortcomings. See R. McCormick \& R. Tollison, Politicians, Legislation, and the Economy: An Inquiry into the Interest-Group Theory of Government 3-5 (1981).

- See Easterbrook, The Supreme Court, 1983 Term-Foreword: The Court and the Economic System, 98 Harv. L. Rev. 4, 17 (1984) (other indicia of rent-seeking legislation include limitations on entry into businesses, subsidies of one group by another, and prohibitions on private contracting in response to new statutory entitlements); see also $R$. McCormick \& $R$. Tollison, supra note 8 , at 49 ("Occupational licensing is a specific and important manifestation of the theory of economic regulation. ... [T]be benefits of licensing accrue to members of the licensed profession in the form of increased rents due to entry limitations and restrictions on price competition within the profession. Moreover, such legislation typically results from lobbying pressure by practitioners in the occupation .....").

10 Posner, supra note 7 , at 265 (arguing that wealth redistribution is a public good no different in kind from protection against crime or pollution; therefore, free-rider problems may thwart private efforts to effect such transfers). 
The second possibility is to design a constitutional system that raises the transaction costs to interest groups of obtaining passage of redistributive legislation. The most obvious way to do this is simply to forbid government officials from doing certain things. Politicians and bureaucrats, however, can easily ignore or misinterpret constitutional provisions when doing so is in their interest. Language is extremely malleable, so even those constraints on governmental action that appear to be the most secure are subject to reinterpretation. In addition to providing verbal commandments to officials and their constituents, constitutions can organize the structure of government so as to raise the costs of rent-seeking. This Article posits that this sort of constitutional protection is the most effective means of controlling post-constitutional interest group opportunism; it provides the greatest hope for lasting constitutional protection against the problem of faction.

Part II of this Article also presents some tentative conclusions, drawn from the economic theory of legislation, about the role of constitutions in social ordering. Finally, Part III arrays the model developed in Part II against the backdrop of the United States Constitution and suggests ways that a transaction-costs analysis may be applied to evaluate constitutions.

\section{The Economics of Legislation: Studied Positivism}

The modern economic theory of legislation can be summarized easily. To use Judge Richard Posner's description, the economic (or "interest group") theory of legislation "asserts that legislation is a good demanded and supplied much as other goods, so that legislative protection flows to those groups that derive the greatest value from it, regardless of overall social welfare."11 The scholarship that has advanced the economic theory of legislation either comes directly from or has been heavily influenced by one of three sources. The first is the so-called "Virginia School," whose leading exponents are James Buchanan (the 1986 Nobel Laureate in Economics), Gordon Tullock, and Robert Tollison. The second important line of scholarship has been generated by a host of economists and lawyers at the University of Chicago, led by Nobel Laureate George Stigler and including Sam Peltzman, Judge Posner, Wil-

11 Id. 
liam Landes, and Gary Becker. Finally, economists and political scientists affiliated with the University of Maryland, particularly Mancur Olson, have made seminal contributions to the literature on interest groups and political life.

\section{A. The Current State of the Literature}

The many works of these economists and lawyers, though exceedingly wide-ranging in scope, share two common elements. First, they have advanced the economic theory of legislation by focusing on the differing organizational costs that face rival political coalitions. Basically, efficiency considerations indicate that a group forms into an effective political coalition when the benefits from achieving wealth transfers from the legislature outweigh the costs of organizing. For a number of reasons, some groups will be able to organize more cheaply than others; ${ }^{12}$ thus, literature focusing on the factors that influence the costs of forming an effective political coalition explores an extremely important avenue of research. If those groups that are likely to organize into effective political coalitions can be identified ex ante, then the nature of their preferences can be specified, and likely legislative outcomes can be predicted.

The second, and perhaps more important, common element is the remarkable absence of normative tone in the serious, scholarly literature on the economic theory of legislation. As Professor Tollison remarks in his contribution to this Symposium, the issue is not "whether a law is 'good' or 'bad,' but why the law was passed, how the law was passed, why it has not been repealed, and so on."13 In providing his excellent survey of the current public choice literature, Tollison goes on to point out that "the use of 'interest group' as a modifier [in the literature on the economic theory of legislation] is not meant to be pejorative."14 Indeed, Judge Posner has identified the positive-normative dichotomy as the principal difference between the modern economic theory of legislation and the traditional view of legislation. Posner claims that the economic

\footnotetext{
12 See R. McCormick \& R. Tollison, supra note 8, at 16-18; M. Olson, The Rise and Decline of Nations: Economic Growth, Stagflation, and Social Rigidities 18 (1982).

is Tollison, supra note 3 , at 339 .

14 Id. at 341.
} 
approach is (and should be) purely positive, whereas the traditional approach was predominantly normative. ${ }^{15}$

At one level, there is good reason for the decidedly descriptive tone of the current literature. The interest group theory of legislation predicts that laws are passed because some interest group has provided political support to the relevant political operatives in levels sufficient to obtain the desired legislation. This conclusion, however, tells us nothing about whether the law is "good" or "bad" from a normative standpoint. Although the interest group may have obtained passage of the statute simply to effect a wealth transfer from some less powerful group to itself, the interest group's efforts may nevertheless advance overall social welfare by promoting the production of a public good, or by overcoming some free-rider difficulty that impedes the market's ability to solve a particular problem. ${ }^{16}$ Thus, the economic theory of legislation focuses narrowly on the mechanics of the legislative process, not on whether the outcomes generated by this process offer a net benefit to society. Nonetheless, public choice theory does contain profound normative implications.

\section{B. Descriptive Gaps and Normative Implications}

One normative implication of the economic theory of legislation emerges even from the foregoing thumbnail description of the theory. The earlier, naive view of legislators as public-regarding guardian angels who meet periodically to right the wrongs of society has been thoroughly discredited.17 It has been replaced by a more accurate vision of the legislature as a marketplace, which generates a variety of outcomes, only some of which provide a net

${ }^{15}$ See Posner, supra note 7, at $263 \&$ n.1 (describing the economic theory of regulation as a positive theory "breaking with the older, predominantly normative tradition"). But cf. id. at 266 ("From a normative standpoint, therefore, the interest group theory is pessimistic concerning the purpose and effects of legislation .....").

${ }^{16}$ See Becker, supra note 3, at 384-85 ("[P]olitical policies that raise efficiency are more likely to be adopted than policies that lower efficiency"). Policies that increase efficiency are likely to be adopted because such policies are less likely to be opposed successfully by rival interest groups. Activities that benefit all groups will rationally be opposed by no groups. Such policies will be adopted if they receive even lukewarm support from one or more interest groups. See id. at 383 . The difficulties arise when certain groups press for policies that increase efficiency but also entail the taxation or regulation of other groups.

${ }^{17}$ See Kalt \& Zupan, Capture and Ideology in the Economic Theory of Politics, $74 \mathrm{Am}$. Econ. Rev. 279, 279 (1984). 
benefit to society. The outcomes generated by this marketplace reflect a political equilibrium that in turn reflects the relative strengths of rival groups..$^{18}$

From this more sophisticated vision of government emerges a whole new-and admittedly normative-view of the role of law in society. If, in fact, a democratically elected legislature cannot be trusted to act consistently in the public interest, then even those who advocate an expanded role for government must see the need for some constraint on the lawmaking process. From a public choice perspective, however, the role of the legal system is not simply to restrain interest groups, but rather to serve as a filter, sifting out and discarding legislation that is simply redistributive and serves no useful societal purpose, while permitting legislation that does more than provide wealth transfers from the politically powerful to the politically weak.

It must be emphasized that even in its current, purely descriptive incarnation, the economic theory of legislation provides a far richer picture of the lawmaking process than does its public interest rival. Nonetheless, the glaring gap in the normative content of the current literature should be filled. ${ }^{19}$

\section{Private vs. Public Ordering}

Both the economic theory of legislation and traditional microeconomic analysis identify two possible methods by which individuals and firms can increase their stock of wealth. First, microeconomic theory describes the market transaction mechanism through which firms and individuals create wealth. Such transactions benefit not only the individual parties to the transaction but also society at large, as entrepreneurs are "coaxed by competitive forces to provide what others want on improved terms, a serendipi-

${ }^{18}$ The interest group political equilibrium analysis began witb a pioneering book by Arthur Bentley. See A. Bentley, The Process of Government 258-59 (1967) ("Pressure . . indicates the push and resistance between groups. The balance of the group's pressure is the existing state of society."). Pathbreaking contributions to the theory have come from Becker, supra note 3; Peltzman, supra note 3; Posner, Theories of Economic Regulation, 5 Bell J. Econ. \& Mgmt. Sci. 335 (1974); Stigler, supra note 3.

10 This gap has been noticed by others. See Buchanan, Comment, 18 J.L. \& Econ. 903, 904-05 (1975) (urging careful separation of the positive from the normative); Tollison, Comment, in Constitutional Economics: Containing the Economic Powers of Government 59 (R. McKenzie ed. 1984) [hereinafter Constitutional Economics]. 
tous benefit to the public that was in no way a part of the entrepreneur's intentions."20 For this reason, an emerging group of "constitutional economists" have considered forcing transactions out of the political sphere and into the private sector to increase societal wealth and overall utility-an important purpose of a properly functioning constitution. ${ }^{21}$

Alternatively, firms and individuals seeking profits can turn to the legislative arena, where wealth is transferred rather than created. In the real world, of course, we observe firms pursuing both strategies simultaneously. The automobile industry, for example, expends resources making cars, but it also expends resources lobbying to obtain rent-seeking legislation. At the margin, firms will choose to divert their resources from one activity to another, depending on which investment appears to offer the highest return.

Unlike wealth creation, which increases societal wealth, rentseeking imposes several significant costs on society. The most widely understood external costs are those that third parties encounter when they attempt to block legislation that threatens to transfer wealth from those third parties to the rent-seeking interest groups. In addition, rent-seeking is inefficient because it can result in several forms of deadweight social losses. For example, deadweight social losses will occur to the extent that interest groups seeking wealth transfers must expend resources to obtain those transfers. ${ }^{22}$ As Judge Posner and others have pointed out, an interest group will find it efficient to expend up to $\$ 99.99$ to obtain a $\$ 100.00$ wealth transfer. ${ }^{23}$ This $\$ 99.99$ is a deadweight social loss; the figure represents a sum that could have been spent to create wealth. Deadweight social losses also occur when legislation creates truly unnecessary regulation that imposes greater costs on some firms than others, thus giving certain firms a competitive edge. Where such regulations exist, deadweight loss results as the parties

20 The point, of course, is Adam Smith's; the expression is Richard McKenzie's. See McKenzie, Introduction, in Constitutional Economics, supra note 19, at 4.

21 Id.

${ }^{22}$ See Tullock, The Welfare Costs of Tariffs, Monopolies, and Theft, 5 W. Econ. J. 224, 228-30 (1967).

${ }^{23}$ See Posner, The Social Costs of Monopoly and Regulation, 83 J. Pol. Econ. 807, 812 (1975); Rogerson, The Social Costs of Monopoly and Regulation: A Game-Theoretic Analysis, 13 Bell J. Econ. 391, 391 (1982). 
subject to the regulation must expend resources to comply with the regulation. ${ }^{24}$

Another, more subtle cost of interest group regulation, recently described in an important article by James Alm, is that it prompts economic resources to be diverted from more valued to less valued-but unregulated-uses. ${ }^{25}$ Finally, the power of the government to effect wealth transfers imposes costs even on markets that appear to be operating free of governmental intrusion; even in such unregulated markets, economic actors must expend resources to keep their markets clear of governmental regulation. This phenomenon has recently been labeled (quite graphically) as "rent extraction." "26 It is distinguishable from the more widely recognized legislative practice of "rent creation," by which government creates a cartel for a particular industry subgroup by enacting regulations that favor that group at the expense of consumers or rival producers. $^{27}$

In sum, economic actors expend vast amounts of resources to obtain rent-seeking legislation, to comply with it, to avoid having to comply with it, to adjust to it, and to prevent it from being enacted in the first place. All of this activity is dealt with thoroughly-at a descriptive level-in the existing public choice literature. Perhaps it is best summarized by Mancur Olson's description of three imphications of the interest group model of political behavior. ${ }^{28}$ First, "special-interest organizations and collusions reduce efficiency and aggregate income in the societies in which they operate and make political life more divisive."29 Second, interest group coalitions organized to effect wealth transfers "slow down a society's capacity to adopt new technologies and to reallocate resources in response to changing conditions, and thereby reduce the rate of economic growth."30 Finally, distributional coalitions increase "the complex-

\footnotetext{
${ }^{24}$ See Tullock, supra note 22 , at 225 . In addition, products produced in cartelized environments cause deadweight social losses because consumers must pay more for tbem. Id.

${ }^{25}$ Alm, The Welfare Cost of the Underground Economy, 23 Econ. Inquiry 243, 243 \& n.1 (1985).

${ }^{28}$ McChesney, Rent Extraction and Rent Creation in the Economic Theory of Regulation, 16 J. Legal Stud. 101, 102-03 (1987).

${ }^{27}$ See id. at 103; see also Stigler, supra note 3, at 5-6 (providing the basis for the idea of "rent creation").

${ }^{28} \mathrm{M}$. Olson, supra note 12 , at 74 .

20 Id.

so Id.
} 
ity of regulation, the role of government, and the complexity of understandings," 31 thereby retarding the social evolution of a society and raising the costs of all forms of economic activity.

\section{Unanswered Questions}

From the existing economic model of legislation, one burning question emerges: Why is there any economic growth at all, given the power of the modern Leviathan which, acting as the arm of powerful interest group coalitions, steals the proceeds of such wealth creation through taxation and regulation? The economic theory of legislation seems to have no ability to predict whether wealth transfer activities will cease before they strip society of all of its capacity to produce wealth. Indeed Professor Olson has argued that special interest groups' tendency, in stable industrial societies, to organize into effective political coalitions to bring about wealth transfers to themselves from less powerful groups implies that democratic economic systems will ultimately crumble, as governments slowly but systematically remove private parties' incentives to create wealth. ${ }^{32}$

The most casual empirical analysis indicates, however, that something is profoundly wrong with that theoretical model. We observe stable societies that enjoy remarkable growth. The postwar economic successes of Japan and Germany, and the long-term stability of Switzerland, are obvious examples, but even Hong Kong, South Korea, Singapore, and the recent reemergence of Great Britain's economy present serious analytical problems for the current interest group paradigm.

\section{Constitutions and Incentives}

The current scholarship fails to recognize (indeed, it seriously disputes) that a fully informed (and non-suicidal) populace has strong incentives to design a system of government that regulates the future wealth transfer activities of interest groups. In light of the fact that interest group legislation benefits pohitically powerful subgroups within society, at first blush the proposition that a consensus blocking such transfer activity could win widespread sup-

${ }^{31}$ Id.

32 Id. at 77. 
port seems counterintuitive. The argument, however, becomes far more plausible when one recognizes that each interest group is comprised of private citizens who lose more often than they gain from wealth transfer activity. A simple example demonstrates the point. If an interest group spends $\$ 50.00$ to obtain $\$ 100.00$ in wealth transfers, gains from trade can be realized if the transferors (i.e., the taxpayers) agree to pay the beneficiaries $\$ 51.00$ to refrain from seeking the transfer. The rent-seekers have gained $\$ 1.00$, and the transferors have gained $\$ 49.00$ in the form of regulatory forbearance.

By agreeing ex ante (i.e., at the time of constitutional creation) to constrain rent-seeking, everyone can be made better off, because even those few who expect to be net winners from the wealth transfer game can be induced through side payments to support a constitutional structure that restricts coercive, inefficient wealth transfers. Thus, the interest group dynamic during times of constitutional creation may be completely different than during times of ordinary politics-when wealth transfers dominate the political landscape. The fundamental difference between the incentives that face lawmakers (and private citizens) during times of constitutional creation and the incentives that face lawmakers during times of ordinary politics explains why constitutions are likely to be more public-regarding than statutes. ${ }^{33}$

The economic historian Douglass North provides the basis for an important additional reason why constitutions are likely to contain rules that embody a broader conception of the public interest than the rules generated in the normal course of legislative life. ${ }^{34}$ In his theory of the state, North posits that the state is constrained "by

s3 I have described the incentives that exist during periods of constitutional creation elsewhere:

Individual members of a particular special interest group are hurt as much as any member of the public by any special interest legislation not specifically designed to benefit their group. . . . Thus, even special interest groups that might benefit from some specific, discrete legislative wealth transfers are likely to object to general constitutional provisions that facilitate rent-seeking.

Macey, Promoting Public-Regarding Legislation Through Statutory Interpretation: An Interest Group Model, 86 Colum. L. Rev. 223, 246-47 (1986) [hereinafter Macey, Promoting Public-Regarding Legislation]; see also Macey, Competing Economic Views of the Constitution, 56 Geo. Wash. L. Rev. 501, 525-26 (1987) (explaining the incentives facing interest groups in times of ordinary politics in terms of the prisoner's dilemma).

${ }^{34}$ North, A Framework for Analyzing the State in Economic History, 16 Explorations Econ. Hist. 249 (1979). 
the opportunity cost of its constituents."3s Because potential substitutes for the existing regime always exist, the state will find it relatively difficult to extract wealth from its constituents if there are other states to which its constituents may move at low cost, or if some individuals within the state may attempt to displace the existing government. ${ }^{36}$

The reasons for the phenomenon articulated by North are straightforward. First, individuals involved in wealth-producing activities may find it advantageous to move to another jurisdiction rather than face high taxes and stiff regulation. By hypothesis, as such movement becomes more costly, state regulation, at the margin, becomes less costly for the state. Given increasing movement costs, each additional increment of regulation costs the state less because some firms may elect to stay and face the higher taxes and increased regulation rather than bear the costs of moving. In Professor North's words:

The ruler always has rivals: competing states, or potential rulers within his own state. . . . Where there are no close substitutes, an existing ruler will be characterized as a despot, a dictator, or an absolute monarch. The closer the substitutes, the fewer degrees of freedom the ruler possesses, and the greater the percentage of incremental income that will be retained by the constituents. ${ }^{37}$

North's emphasis on the effect of competing regimes on the configuration of legal rules provides an important reason why constitutions are less likely than garden-variety legislation to exhibit exploitive characteristics. At the time constitutions are formed, rival governments and competing forms of government are likely to provide citizens with an effective and meaningful choice of governmental structure. The history of the United States Constitution is a striking manifestation of this phenomenon. Today, laws may impose large costs on the public before reaching the point at which leaving for another country would be less costly than compliance. By contrast, however, when the Constitution was being debated,

${ }^{35}$ Id. at 252 ("The rivals are other states, as well as individuals within the existing political-economic unit who are potential rulers. The degree of monopoly power of the ruler therefore is a function of the closeness of substitute for the various groups of constituents.").

${ }^{36}$ See id. at 255 \& n.5 (citing A. Hirschman, Exit, Voice and Loyalty (1970)).

${ }^{37} \mathrm{Id}$, at 255. 
there was a strong possibility that the states would not ratify the document. Indeed, the main issue at the constitutional convention was whether the states should form together into a proper national government at all. Ratification was by no means assured when the document was being formulated. ${ }^{38}$

The purpose of the Philadelphia convention was to solve a number of serious problems that had arisen in the state legislatures during the decade after the Revolution. The period in question was marked by extraordinary economic expansion, ${ }^{39}$ and the proponents of the Constitution argued that the current structure of government (i.e., the Articles of Confederation) had to be amended to maintain this growth. ${ }^{40}$ As the defenders of the new regime repeatedly pointed out, capital formation would not be possible "if an omnipotent legislature can set aside contracts ratified by the sanction of law."41

The state governments, however, were promulgating a rash of laws that benefited only a narrow band of special interests, particularly debtor landholding interests. The "legislative department"

ss The reason The Federalist was written and circulated was to provide a forum in which the authors and supporters of the Constitution could explain and defend the document. See The Federalist, at viii (C. Rossiter ed. 1961) (describing The Federalist as "only one of several hundred salvos in the loud war of words that accompanied the protracted struggle over ratification of the Constitution"). Professor Rossiter stated further:

[Few of the] authors and supporters [of the Constitution] imagined that it would be easy to win such a margin of approval [nine of the thirteen states] in the chaotic political circumstances of the world's first experiment in popular government over an extended area; all recognized that a clear-cut vote against the Constitution in any one of four key states would be enough by itself to destroy their hopes for "a more perfect union."

Id.

${ }^{30}$ M. Jensen, The New Nation: A History of the United States During the Confederation, 1781-1789, at 423-24 (1965).

$10 \mathrm{G}$. Wood, The Creation of the American Republic, 1776-1787, at 393-96 (1969).

4 Id. at 406 \& n.22 (quoting from Rusticus, On Ex Post Facto Laws, 2 Am. Museum 169, 170 (1787)). The framers appealed to pubhic stability and order in their defense of the new constitutional government. As one author of The Federalist observed:

The want of confidence in the public councils damps every useful undertaking, the success and profit of which may depend on a continuance of existing arrangements. What prudent merchant will hazard his fortunes in any new branch of commerce when he knows not but that his plans may be rendered unlawful before they can be executed? What farmer or manufacturer will lay himself out for the encouragement given to any particular cultivation or establishment, when he can have no assurance that his preparatory labors and advances will not render him a victim to an inconstant government?

The Federalist No. 62, at 381-82 (probably J. Madison) (C. Rossiter ed. 1961). 
in each state, as James Madison observed, was "everywhere extending the sphere of its activity and drawing all power into its impetuous vortex." 42 The law promulgated by state legislatures, according to Gordon Wood, was "becoming contemptible in the eyes of those [prominent citizens and jurists] from whom it traditionally should have commanded the greatest respect."43 Thus, a key complaint underlying the demand for a new form of government was that the state governments were governing too much-not that they were not governing enough. Unlike its rival state constitutions, the new Constitution was designed to protect the rights of ordinary citizens from the state legislatures, dominated by interest groups, which were choking off the economic hife of the states.

In sum, the history of the birth of the Constitution is consistent with Professor North's argument regarding the effect that rivalrous competition has on political outcomes. The adoption of the Constitution was marked by a strong and informed debate over which of a number of forms of government would best maximize the welfare of the people. Such competition at the time of constitutional formation is more likely to produce a government that deprives the ruler of discretion and permits a greater percentage of wealth to be retained by the constituents to whom it belongs. ${ }^{44}$

This discussion merely provides an explanation, in terms familiar to the economist, of what Professor Bruce Ackerman has described as "constitutional moments," those "rare periods of heightened political consciousness" when private citizens appear to rise up in a communitarian collectivity to press for laws that benefit society as a whole rather than narrow economic interests. ${ }^{45}$ Ackerman has attributed the existence of constitutional moments to

42 The Federalist No. 48, at 309 (J. Madison) (C. Rossiter ed. 1961); see also R. McCormick, Experiment in Independence: New Jersey in the Critical Period, 1781-1789, at 183 (1950) (state legislation was "founded not upon the principles of Justice, but . . . upon the Right of the Sword").

43 G. Wood, supra note 40 , at 406.

"See North, supra note 34, at 255. The use of the term "belongs" adopts John Locke's conception of property rights, which posited that people rightfully acquire ownership of property by mixing their labor with property that was previously unowned. J. Locke, Two Treatises of Government 328-29 (P. Laslett rev. ed. 1963) (3d ed. 1698); see also Sanders, Justice and the Initial Acquisition of Property, 10 Harv. J.L. \& Pub. Pol'y 367, 369-76 (1987) (discussing the Lockean theory of property).

${ }^{4}$ Ackerman, The Storrs Lectures: Discovering the Constitution, 93 Yale L. J. 1013, 1022 (1984). 
altruism and what he describes as "revolutionary wisdom."46 I suggest, perhaps more realistically (and certainly more cynically), that rational self-interest-utility maximization, in economic terms-leads to constitutional moments such as the one that occurred in 1787.

Public choice theorists have strongly rejected this dualistic conception of political life, which sharply differentiates "normal politics" from "constitutional politics." adigm draws no distinction between times of ordinary politics, when interest groups pursue their own narrow ends, and constitutional moments, when the collective action problems that ordinarily thwart the public interest can be overcome and legislation that effects wealth transfers can be replaced by legislation that instead facilitates wealth creation. ${ }^{48}$

\section{Raising Transaction Costs: The Role of Constitutions in} A Rent-SeEking Society

Having placed the existence of constitutional moments in economic terms, we must examine the likely goals of the drafters of a public-regarding constitution. Again an economic model will prove useful.

Perhaps the most fundamental precept of microeconomic theory is that people act as rational, utility-maximizing individuals. This model guided the framers of the United States Constitution as well. Daniel Patrick Moynihan has observed that at the constitutional convention of 1787 , a government was founded on "scientific

48 Id. at 1020 .

17 Id. at 1022.

${ }^{48}$ See, e.g., Crain \& Tollison, Constitutional Change in an Interest-Group Perspective, 8 J. Legal Stud. 165 (1979); Crain \& Tollison, The Executive Branch in the Interest-Group Theory of Government, 8 J. Legal Stud. 555 (1979) [hereinafter Crain \& Tollison, The Executive Branch]; Landes \& Posner, The Independent Judiciary in an Interest-Group Perspective, 18 J.L. \& Econ. 875 (1975).

A quotation from Robert Tollison illustrates public choice's failure to distinguish between ordinary legislation and constitutional provisions:

[C]onstitutional provisions [are seen] as legislation of a higher order. Constitutional provisions are worth more than normal legislation to interest groups because they are more durable (i.e., harder to repeal), but they are also more costly to obtain because of stricter procedures required for passage (e.g., higher voting rules and a public referendum).

Tollison, supra note 3, at 346 (discussing Landes \& Posner, supra) (citation omitted). 
principles,"49 but Moynihan's observation can be made more precise. The scientific principles upon which the new American government was formed were in fact economic principles fully consistent with the assumptions that drive the modern economic theory of legislation. Specifically, the drafters of the Constitution desired to create a system of government that would operate under the novel assumption that, in the ordinary course of human affairs, neither the governors nor the governed could be expected to be altruistic, other-regarding beings. Rather, as Irving Kristol has observed, the Constitution reveals "a 'realistic' view of human nature-i.e., a view that is more alert to the absence of human virtues than to their presence, a view that is skeptical of the abihty of human beings to govern themselves without the prior imposition of severe institutional self-restraints." According to Martin Diamond, at the time they drafted the Constitution, the framers took a skeptical view of human nature:

Ancient and medieval thought and practice were said to have failed disastrously by clinging to illusions regarding how men ought to be. Instead, the new science would take man as he actually is, would accept as primary in his nature the self-interestedness and passion displayed by all men everywhere and, precisely on that basis, would work out decent political solutions. ${ }^{51}$

Thus, consistent with basic economic principles, the framers of the Constitution assumed they were establishing a system of government that would guide the affairs of rational, highly self-interested economic actors who would be governed by otlier equally self-interested individuals. As the citations above indicate, this point is by no means obscure to those who have studied the perspectives of the framers. What is not so well understood is the

19 Moynihan, The "New Science of Politics" and the Old Art of Government, 86 Pub. Interest 22, 22 (1987).

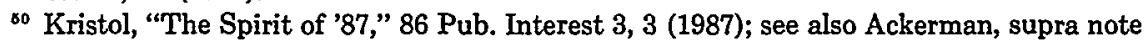
45 , at 1020 ("The Federalist's task is to construct the constitutional foundations for a different kind of politics-where well-organized groups try to manipulate government in pursuit of their narrow interests."); Malbin, Factions and Incentives in Congress, 86 Pub. Interest 91, 92 (1987) (discussing federalists' desire to promote diversification of private interests and competition among private interests).

${ }^{81}$ This passage appears with attribution, but without citation, in Moynihan, supra note 49, at 23; see also Diamond, Ethics and Politics: The American Way, in The Moral Foundations of the American Republic 46 (R. Horwitz $2 \mathrm{~d}$ ed. 1979) (making a similar point). 
mechanism by which the framers translated their notions of human behavior into a constitutional framework.

This historical inquiry raises three important questions for the application of public choice theory to constitutional analysis. First, what, if anything, can constitutions do to constrain the rent-seeking activity that is bound to follow the initial enactment of even the most public-regarding constitution? Second, is it possible to develop a constitutional framework that will eliminate rent-seeking? If, as will be argued, it is not possible or desirable to eliminate rent-seeking, what determines the "optimal" level of rent-seeking activity within a society? The answer to this question raises the issue of how one develops a normative framework for evaluating a constitution. Finally, what light does this normative framework throw on the question of whether the Constitution is performing as it was intended-i.e., is it controlling interest group politics? The following Sections address these questions.

\section{A. What Constitutions Can Do About Rent-Seeking: Two Strategies}

Constitutional drafters can employ two strategies to improve the quality of political life in the post-constitutional era. The first is to establish a set of incentives for political actors that provide them with self-interested reasons to refrain from engaging in wealth-reducing political activities. In other words, by assuming that public officials often will act out of self-interest, ${ }^{52}$ those who draft a constitution can attempt to design a system that will cliannel the incentives of such officials in directions that are consistent with the public interest rather than with special interests. The second strategy that constitutional drafters can employ is to design a constitutional system that raises the costs of interest group activity in the post-constitutional era. By raising the costs of influencing political outcomes, such a constitutional scleme would reduce the incidence of rent-seeking activities and thus increase societal wealth.

\section{Creating Incentives}

The problem facing constitutional drafters in creating the proper set of incentives for subsequent political actors closely parallels the

32 See Malbin, supra note 50, at 92. 
conflict that arises from the "separation of ownership and control" in a large, publicly held corporation. ${ }^{53}$ Specifically, corporate managers and directors can be likened to bureaucrats and legislators in that they are agents of a large, diverse, and disorganized group of principals. This organizational structure leads to a divergence of interests between the principals and agents. Recent theoretical and empirical research in the area of corporate finance suggests, however, that different firms encounter different degrees of managerial divergence, depending on a wide array of variables. For example, a firm that is a ripe target for an external hostile takeover is likely to experience less divergence between shareholder interests and managerial interests than a firm that is insulated from all threats of outside influence. ${ }^{54}$ Managers are likely to attempt to maximize share value (i.e., act in shareholders' interests) to retain their jobs when their control of the corporation is realistically threatened. ${ }^{.5}$ Similarly, when the product markets in which a firm competes are strongly competitive, managers find shirking more difficult. ${ }^{56}$

In applying these lessons from corporate finance to political theory, one reaches conclusions identical to those of Professor North. That is, where there is competition among providers of legal rules, political leaders are constrained in the sorts of rules they can create. ${ }^{57}$ This phenomenon was discussed above in the context of the incentives that face constitutional actors at the time they are drafting a constitution. A constitution is likely to be more publicregarding if the drafters face competition from those with different constitutional visions. Similarly, constitutional drafters may wish

${ }^{33}$ The notion of the "separation of ownership and control" in the large, publicly held corporation was popularized by Adolf Berle and Gardiner Means. See A. Berle \& G. Means, The Modern Corporation and Private Property (1932). For a sampling of the literature, see Fama, Agency Problems and the Theory of the Firm, 88 J. Pol. Econ. 288 (1980); Fama \& Jensen, Agency Problems and Residual Claims, 26 J.L. \& Econ. 327 (1983); Fama \& Jensen, Separation of Ownership and Control, 26 J.L. \& Econ. 301 (1983); Williamson, Organizational Form, Residual Claimants, and Corporate Control, 26 J.L. \& Econ. 351 (1983).

54 See Easterbrook \& Fischel, The Proper Role of a Target's Management in Responding to a Tender Offer, 94 Harv. L. Rev. 1161, 1168-75 (1981); Haddock, Macey \& McChesney, Property Rights in Assets and Resistance to Tender Offers, 73 Va. L. Rev. 701, 701-02 (1987).

${ }^{s s}$ See Manne, Mergers and the Market for Corporate Control, 73 J. Pol. Econ. 110, 11213 (1965).

${ }^{58}$ See Winter, State Law, Shareholder Protection, and the Theory of the Corporation, 6 J. Legal Stud. 251, 262-64 (1977).

${ }^{67}$ See supra notes 34-44 and accompanying text. 
to establish a regime that fosters competition among political actors in the post-constitutional era, to provide incentives for politicians to refrain from activities that are contrary to the interests of their constituents.

Although constitutional drafters can design a system that fosters competition and thus provides incentives for political actors to act in ways that benefit their constituents, it is difficult to imagine a constitutional regime that would replicate the competitive situation found in the market for corporate control. In some respects, political parties represent competing firms. To achieve control of the apparatus of government, political parties compete in offering attractive platforms to voting coalitions. Just as experts in corporate finance have recognized that the market for corporate control pits rival management teams agamst one another in a bidding war for control of the corporate enterprise, ${ }^{58}$ so too do political elections pit rival political teams against one another in a struggle to control the machinery of the state.

Although this last analogy appears to be apt, in fact, the competition between political parties and the competition in the market for corporate control significantly differ. The problem is one of information costs. Shareholders of firms can easily evaluate competing tender offers for their shares; their shares are traded publicly and have a readily ascertainable market price. The management team that places the highest value on the right to manage the target firm will be the one that can manage the firm most effectively. This team is in a position to outbid other firms for the right to control the resources of the target firm.

By contrast, voters cannot inexpensively ascertain the value of rival political parties. Voters face a massive free-rider problem that provides a disincentive to invest resources in searching for information about rival political actors. All of the costs of such a search are borne by the citizens who conduct the search, while the benefits are shared among all members of the polity..$^{59}$ Competition among political parties, therefore, is not likely to have the same

ss See Jensen \& Ruback, The Market for Corporate Control: The Scientific Evidence, 11 J. Fin. Econ. 5, 6 (1983) ("We view the market for corporate control, often referred to as the takeover market, as a market in which alternate managerial teams compete for the rights to manage corporate resources.").

s9 See M. Olson, The Logic of Collective Action: Public Goods and the Theory of Groups 16 (1971). 
beneficial effect on the governmental process as competition among bidders has in the market for corporate control.

Paradoxically, the problem of obtaining access to reliable information about political functionaries may be so great that increased competition in the political sphere may lead to more, rather than less, rent-seeking activity. Political parties, recognizing the phenomenon of voter apathy due to rational ignorance, compete for the right to divert resources from the general population to those interest groups most adept at overcoming the free-rider problem. Politicians acquiesce because they recognize that pursuing this strategy brings them far more political success, in the form of interest group support, than it costs them in mass constituent support. The politician who can make the most credible promises to deliver legislative favors to effective interest groups will win. In this way, rent-seeking becomes the dominant form of political expression in times of ordinary politics. Politicians who adopt alternative strategies (such as pursuing a policy of maximizing social welfare) lack sufficient political support and ultimately will be driven from the political market through a classic Darwinian market process.

As Professor Tollison has observed, the role of the politician in this model is that of a broker. ${ }^{60}$ The politician matches those who are in a position to pay the most for interest group legislation with those who are in the worst position to object to it. ${ }^{61}$ Those who are able to pay the most for legislation become the beneficiaries of the resulting wealth transfer, and those who are least able to object become the (often unwitting) bearers of the resulting burden. Thus, competition among individual politicians and political parties is unlikely to generate an effective constraint on interest group activity. ${ }^{62}$

Bo Tollison, supra note 3 , at 343 .

BI Id.

62 Casual empiricism provides support for this conclusion. Increasing the number of pohtical parties appears to increase rather than decrease the level of interest group activity within a country. For example, Israel and Italy have numerous pohitical parties, and both countries bave experienced high levels of factionalism and interest group transfer activity in the past decades. Such activity has resulted in significant periods of hyperinflation. On the other band, as Gordon Tullock has pointed out, countries with only one political party (i.e., dictatorships) also experience extremely high rates of interest group transfer activity. Tullock, Industrial Organization and Rent Seeking in Dictatorships, 142 Zeitschrift für die Gesampte Staatswissenschaft (J. Institutional \& Theoretical Econ.) 4 (1986). This analysis 
If rivalrous competition among political parties is not an effective mechanism for encouraging politicians to act in the public interest, perhaps more direct incentive schemes hold more promise. To take another lesson from corporate finance, executives and directors commonly have a large portion of their compensation packages tied directly to the performance of the firms for which they work. ${ }^{63}$ The absence of a pricing system by which to measure political performance, however, renders such a straightforward application of corporate finance principles to the political context unfeasible.

For example, compensation levels for executives are typically linked to share price performance, because the share price reflects both the current, observable performance of the firm and expectations about the firm's future performance (discounted to present value). Thus, those with an interest in a particular firm can easily monitor the firm's present performance and its expected future performance. No analogous measure of a politician's performance exists, however, and this lack of any appropriate benchmark for measuring and monitoring political performance is one of the primary justifications for adopting a political regime that replaces governmental decisionmaking with the private ordering of the marketplace.

Conceivably, elected officials could be compensated based on the growth in gross national product (GNP). Unlike share prices, however, the GNP measures only current output. Such a compensation scheme would provide strong incentives for politicians to favor short-term growth at the expense of long-term considerations. To maximize their wealth, politicians might sacrifice investments in projects with long-term benefits, such as developing and maintaining the infrastructure of highways and bridges or providing for national defense, in favor of investment strategies that would produce short-term growth in the GNP.

leads to the conclusion that the optimal number of rival political parties may be small. Of course, a dictator's ability to impose his will on the people will be greatly affected by the number of substitutes for his services; potential competition in dictatorships comes in the form of coups d'etat. See id. at 11 (describing the overthrow of the dictator of Sudan when he raised subsidized food prices).

${ }^{63}$ See Easterbrook, Managers' Discretion and Investors' Welfare: Theories and Evidence, 9 Del. J. Corp. L. 540, 554 (1984). 
Similarly, the compensation of elected officials could be linked to the level of unemployment: paying more to the ruling political party when unemployment rates were low, and perhaps imposing sanctions when unemployment rates were high. Besides the obvious problems of distinguishing the performance of individual political actors, such a policy could produce perverse incentives for politicians and could lead to disastrous results. Specifically, linking compensation to the level of employment would provide political actors with little incentive to pursue important goals such as combating inflation, while it would provide them with strong incentives to increase the size of debt-financed governmental spending to keep employment levels high.

In sum, apart from providing for competition among governmental jurisdictions by permitting firms and individuals to move freely from one jurisdiction to another, the standard strategies used in corporate governance for providing incentive mechanisms to induce optimal behavior within the firm cannot be replicated easily in the political sphere. Unlike the corporate sphere, with its public market for shares, nothing in the political realm provides outside observers (i.e., the electorate) with a low-cost mechanism for observing and evaluating the performance of the relevant participants (i.e., elected officials) ${ }^{64}$

84 In a recent important article, Michael J. Malbin suggests that a constitutional system that channels a legislator's political ambitions for greater power and higher office will tend to induce legislators "to look beyond the immediate wishes of a local constituency." See Malbin, supra note 50 , at 95 . The framers assumed that politicians act out of self-interest, but they believed that institutions of government could be "shaped to encourage, control, and then channel ambition toward politically desirable ends." Id. at 93. In Malbin's view, the structure of the legislative system can be arranged so that pohitical ambition forces politicians to seek the respect of their colleagues, and this desire for collegial respect is "an important counterweight to constituency pressure for the ambitious politician." Id. at 95. An added benefit of this sort of legislative framework is that it induces higher-quality candidates to seek office. People who are unwilling to make the political concessions necessary to prevail over rivals in unseemly local elections may enter the political arena if their political futures will be in the hands of their peers, rather than their constituents.

Malbin uses this theory to justify and defend filling political offices by appointment or by indirect election. Id. at 93-96. His theory, however, ignores the impact of logrolling on the political process. Logrolling is simply the process of vote trading in which one legislator agrees to support a particular law in exchange for another legislator's agreement to support a different law. See D. Mueller, Public Choice 49-58 (1979). This sort of logrolling can lead to too much government spending, see Tullock, Some Problems of Majority Voting, $67 \mathrm{~J}$. Pol. Econ. 571, 573 (1959), and to lower overall social welfare, see T. Lowi, The End of Liberalism: Ideology, Policy, and the Crisis of Public Authority 146-56 (1969); Riker \& 
Thus, the only viable way that a constitution can effectively channel the incentives of ordinary political actors to behave in the public interest is by setting up a competitive system of governance-within a federal scheme-and by making exit relatively easy. This method of providing incentives, however, permits a government to impose costs on its constituency up to the point at which such costs become greater than the costs of moving to another jurisdiction. The presence of location-specific investments by particular constituents suggests that a local government can expropriate large amounts of rents before it becomes advantageous for those constituents to move. ${ }^{65}$ As Fred McChesney recently observed, the possibilities of such expropriation must ultimately lead to a lower level of initial investments. ${ }^{66}$

\section{Raising the Costs of Interest Group Activity}

Because of the structural problems inherent in designing a constitutional system that provides the right set of incentives for legislators, incentive-based systems are not likely to initigate the problems of interest group rent-seeking. Fortunately, a constitutional system that raises the costs of interest group activity holds more promise for constraining rent-seeking on the part of interest groups during times of ordinary politics.

A basic presumption of the economic theory of legislation is that, all else equal, increasing levels of expenditures by an interest

Brams, The Paradox of Vote Trading, 67 Am. Pol. Sci. Rev. 1235, 1236 (1973), although the results are arguably indeterminate, see $\mathrm{D}$. Mueller, supra, at 50-58. Thus, so long as elected officials must cater to the whims of their local (interest group) constituencies, removing democratic processes from the structure of government is unlikely to produce beneficial results. The elected officials simply will demand tbat the officials they appoint do as they are told, under the tbreat of removal from office. This logrolling bebavior will undermine any benefits of insulating public officials from the vagaries of elections.

In other words, Malbin is mistaken when be suggests that "[c]oncern for the respect of one's colleagues," coupled with ambition for higher office, will prompt indirectly elected officials to ignore the wishes of narrowly focused constituency groups, see Malbin, supra note 50 , at 95 , because he ignores the likelihood that sucb indirectly elected officials will adopt the interests of their benefactors' constituents as their own in order to advance. If, as seems likely, advancement is not realistically possible for a majority of indirectly elected officials, then Malbin's analysis is even more suspect. In those cases, there is no way to predict how such officials will respond, and to assume that they, like beneficent dictators, will act in the public interest seems naive in the extreme.

${ }^{B 5}$ Cf. Klein, Crawford \& Alchian, Vertical Integration, Appropriable Rents, and the Competitive Contracting Process, 21 J.L. \& Econ. 297 (1978) (discussing post-contractual opportunistic behavior after a specific investment is made).

${ }^{B 8}$ See McChesney, supra note 26, at 108 . 
group on a particular issue increase that group's influence on that issue. ${ }^{67}$ The structure of government, however, greatly affects the marginal price that an interest group must pay to obtain the passage of a particular statute. Thus, constitutional drafters who are concerned about the welfare-reducing influence of special interest groups can design a governmental structure that makes it relatively costly to obtain passage of a statute.

A venerable and straightforward application of the notion that altering the structure of government can affect the cost and thus the production function of legislation was offered by Montesquieu. ${ }^{68}$ Montesquieu argued that a separation of powers between the various functions of government would control governmental abuse by providing a check on the lawmaking ability of rival branches. The principle of separation of powers, advocated by Montesquieu and incorporated in many governmental organizational structures, is a way of increasing the costs to discrete special interest groups of achieving their legislative goals. Establishing a system of government with a separation of powers not only raises the equihibrium price for obtaining passage of a law, it also imposes varying costs on different interest groups, depending on the characteristics of each group and the nature of the legislation.

Every statute has a different effect and will meet with varying degrees of support and opposition from rival interest groups. As support from other groups increases, the costs to a single group of obtaining passage go down, and as opposition increases, the costs go up. Similarly, different groups display varying degrees of efficiency in exerting legislative influence. Relatively small groups and those otherwise able to control the free-riding behavior of members can obtain legislation at a lower average cost than other groups. As McCormick and Tollison explain the situation, "every piece of legislation will have a different demand and supply function so that

67 R. McCormick \& R. Tollison, supra note 8, at 30-31.

68 See C. de Montesquieu, The Spirit of the Laws 151-52 (T. Nugent trans. 1949) (1748) (discussing the value of a separation of powers). Ample evidence contemporary with the drafting of the Constitution suggests that Montesquieu's ideas greatly influenced the framers. See The Federalist No. 9, at 76 (A. Hamilton) (C. Rossiter ed. 1961) (quoting Montesquieu); The Federalist No. 47, at 301 (J. Madison) (citing Montesquieu); The Federalist No. 78 , at 466 (A. Hamilton) (quoting Montesquieu). 
practically speaking, each legislative transaction will carry a separate price." ${ }^{\text {Bg }}$

Establishing several independent branches of government that can block or impede the enactments of rival branches is a means of raising the cost of obtaining legislative enactments for all groups. If a two-thirds vote must be obtained in one elected body to override the veto of the executive, for example, the costs to an interest group of obtaining passage of a statute of which the executive disapproves must also go up. Similarly, if a third branch of government can invalidate or misconstrue (either intentionally or unintentionally) a legislative enactment, then the expected benefit of a statute is necessarily decreased..$^{70}$

In sum, then, the classical justification for the separation of powers is that it raises the cost of special interest legislation by lowering the probability of its ultimately becoming law. This classical view, which I wish to resurrect, is recorded both in The Federalist $^{71}$ and in Buchanan and Tullock's now-famous book, The Calculus of Consent. ${ }^{72}$ As the separation of powers theory is espoused in these sources, judicial review and the executive veto are mechanisms that raise the costs of legislative enactments that do not meet the approval of a majority of voters, for they raise the minimum size of the logrolling coalitions required for passage. Although all of this may appear rather obvious to lawyers and political scientists, the theory of separation of powers as it relates to the interest group theory of legislation is worth noting in some detail, because it conflicts with the dominant paradigm that exists in the economic theory of legislation today.

The current public choice paradigm views the independent, separate branches of government as mechanisms for facilitating rather than impeding interest group activity, because they enhance the durability of the laws passed by the enacting legislature. ${ }^{73}$ In the

69 R. McCormick \& R. Tollison, supra note 8, at 31 .

${ }^{70}$ See Macey, Promoting Public-Regarding Legislation, supra note 33, at 253-54.

71 See The Federalist No. 73 (A. Hamilton) (C. Rossiter ed. 1961) (describing the value of the executive veto); The Federalist No. 78, at 468 (A. Hamilton) (describing the value of judicial review).

72 J. Buchanan \& G. Tullock, supra note 3, at 248.

${ }^{73}$ See Crain \& Tollison, The Executive Branch, supra note 48, at 560-61 (applying Landes and Posner's model to the executive veto); Landes \& Posner, supra note 48 (describing the process as it applies to the judiciary). 
words of Professors Crain and Tollison, if their approach and that of Professor Landes and Judge Posner is correct, it "undermines any semblance of a separation-of-powers argument in favor of [a] tripartite system of government. . . . [W] have not a separation but a collusion of powers in our governmental system."74 The current argument begins with the uncontroversial assumption that the value to a special interest group of achieving passage of a particular statute depends, in large part, on how durable the legislative protection is expected to be. An interest group will not offer much political support for a statute that it expects to be overturned in the near future.

Landes and Posner then argue that establishing an independent judiciary (i.e., one in which judges enjoy life tenure) increases the durability of interest group bargains because judges rarely hold laws unconstitutional and because judicial custom and concern for professionalism cause judges to attempt to interpret laws consistently with the congressional intent. ${ }^{75}$ This argument, however, seems lighly implausible to lawyers who have studied judicial opinions. In the process of applying basic tenets of statutory interpretation, judges often systematically undo the special interest bargains that legislatures have enacted. ${ }^{76}$ An especially glaring omission in the Landes and Posner theory is an explanation for why judges have any incentive to reduce overall societal wealth (including their own) by enforcing interest group deals in which they do not benefit at all.

In his article for this Symposium, Professor Tollison recognizes this problem in the current wisdom and attempts to answer it. Tollison claims that, because the judicial brancl receives its salaries and budgets from the legislative brancll, the judiciary directly benefits through increased salaries and budgets when it acts to sustain the durability of interest group legislation. ${ }^{77}$ This explanation, however, is inconsistent with tlie very theory it purports to defend: Tollison is attempting to support the theory tliat judges' independence increases the durability of interest group bargains by arguing that judges are not independent due to their reliance on the

\footnotetext{
74 Crain \& Tollison, The Executive Branch, supra note 48, at 561.

75 Landes \& Posner, supra note 48 , at 879 , 885-87.

78 See Macey, Promoting Public-Regarding Legislation, supra note 33.

77 Tollison, supra note 3 , at $345-46$.
} 
legislative branch for salary and budget increases. Moreover, if Tollison's explanation is correct, we would expect to see independent judges upholding the legislative enactments of the current members of the legislature to curry favor and gain salary increases, but overturning the enactments of previous legislatures, as judges have little to gain by preserving those earlier enactments.

Tollison's model simply does not describe the pattern of durability that current public choice theory predicts. Indeed, the Landes and Posner theory posits that an independent judiciary increases the durability of interest group deals because judges do not depend on the current legislature for their salaries. In other words, either the judiciary is independent or it is not. Professor Tollison argues that an independent judiciary provides durability for interest group deals because it is dependent on the legislature. Thus, his argument in support of Landes and Posner is a refutation of the very thesis it attempts to defend.

An additional reason why the Landes and Posner view (as refined by Tollison) is likely to be incorrect is that, unlike other economic actors, judges' salaries are not fixed individually. Judges on the same court all earn the same salary and are entitled to identical benefits. As a consequence, judges are in a classic "prisoner's dilemma"78 with respect to one another when it comes to approving legislation designed to curry favor with current legislators. If judges could coordinate their actions, perhaps they would behave as Tollison suggests-i.e., enforce the durability of legislative deals. By following a rational "maxi-min" decision rule, , $^{79}$ however, it is unlikely that a diverse and geographically separated group of fed-

78 The phenomenon, known as the "prisoner's dilemma," is a subset of the economic study of individual behavior in the face of uncertainty; it "is the prototype for many economic problems in which individual rationality in an uncertain situation can lead to an outcome that is completely irrational." W. Nicholson, Microeconomic Theory $165-66$ (2d ed. 1978). Acting in concert, each individual could have been made better off. Due to high informational costs or the costs of collective behavior, however, each individual will follow his own rational self-interest and therefore decide "on a course of action that is in a larger sense irrational." Id. at 165.

72 This rule entails maximizing the chances of obtaining the best possible result under a certain set of constraints while minimizing the chances of obtaining the worst possible result. See J. Henderson \& R. Quandt, Microeconomic Theory 213-16 (3d ed. 1980); see also W. Nicholson, supra note 78, at 166-67 ("This rule states that the individual should choose that strategy for which the minimum possible return is the greatest. This rule is basically a pessimistic one which implicitly assumes that the worst will happen no matter which strategy is chosen."). 
eral judges will act in the interest of judges as a whole by neglecting their own preferences when deciding a case, and substituting the preferences of the legislature for their own..$^{80}$

Were judges simply to validate the interest group bargains, their total costs would likely outweigh any immediate, remunerative gains. The reason is two-fold. First, when a judge is construing a federal statute, his decision will have an immediate and perhaps significant effect on his own utility. Colleagues and academics will be quick to chastise him for a silly or erroneous decision validating or extending a pernicious interest group bargain; the benefit to the judge from such a validation or extension in terms of increased salary and budget is, however, likely to be remote. Second, if other judges are generating outcomes that the legislature finds congenial, then punishing the recalcitrant judge requires punishing the compliant judges as well, because judicial salaries and benefits are adjusted uniformly. This creates an incentive for a judge to attempt to maximize his own utility when deciding cases, hoping that his colleagnes will bear the costs of being pawns of the legislature. The fact that most judges are likely to consider this to be their optimal strategy results in the prisoner's dilemma and strips the Tollison analysis of its vitality.

In another application of the Landes and Posner analysis, Crain and Tollison contend that the nullification of a law by a judge is precisely analogous to the casting of a veto by a chief executive. ${ }^{81}$ They note that in both cases the legislature is generally unlikely to reverse successfully the actions of the otlier branch. ${ }^{82}$ Nonetheless, consistent with the Landes and Posner view of tlie judiciary, Crain and Tollison argue tliat tlie executive veto enliances the returns from legislative bargains with special interest groups by improving their durability. ${ }^{83}$

so The reference in the text to the preferences of judges is meant to suggest only that judges maximize their own utility when they decide cases; it is not meant to imply that judges act selfishly or willfully. Indeed, over a wide range of issues, judges are more likely to maximize their utility by maximizing their prestige within the academic and judicial communities and by maximizing their self-image and sense of self-worth. When judges maximize along these utility vectors, they are likely to generate decisions entirely consonant with what is commonly viewed as the public interest.

${ }^{81}$ See Crain \& Tollison, The Executive Branch, supra note 48, at 560.

82 Id.

ss Id. 
Though Crain and Tollison are correct that the presence of the executive veto increases the difficulty of repealing legislation once it is enacted, one cannot jump from this observation to the conclusion that executive vetoes increase the value of interest group legislation. Vesting the executive with veto power not only makes repealing legislation more difficult, it also makes passage of legislation more difficult to obtain in the first place. Moreover, although executive vetoes occur relatively infrequently, simply counting the number of vetoes is not a good measure of their effect, because it does not take into accoimt the fact that the prospect of an executive veto dissuades interest groups from squandering resources in attempts to gain passage of statutes that they expect will be vetoed.

Even Crain and Tollison's empirical evidence appears to support the view that both the executive veto and the independent judiciary raise the cost of rent-seeking. Using a cross-sectional analysis of state governments, Crain and Tollison have found that the frequency of executive vetoes increases as the size of the majority within the legislature increases. ${ }^{84}$ As Crain and Tollison note, however, the average cost of passing laws declines as the size of legislative majorities increases. ${ }^{85}$ As the cost of passing laws declines, of course, the legislature passes more interest group legislation. Thus, as a legislative majority grows larger, it becomes less costly for interest groups to achieve passage of the legislation they favor. And, consistent with the traditional, public interest theory of the executive veto, the data presented by Crain and Tollison indicate that when this happens the incidence of executive vetoes goes up. In other words, just as legislation becomes less costly for interest groups because of a change in the size of the legislative majority, the incidence of vetoes striking down the proposed enactments goes up, thus restoring the previous balance.

The point of this discussion has been to defend the traditional view of the separation of powers. This view holds that the separa-

\footnotetext{
st Id. at 566.

${ }^{\text {gs }}$ Id. at 562 \& $\mathrm{n} .18$ (citing Crain \& Tollison, Team Productivity in Politics, 2 Micropolitics 111, 114-15 (1982)). Crain and Tollison illustrate this conclusion by analogizing a legislative majority to the controlling interest in a publicly held corporation. A shareholder who controls a large block of shares is better able to implement his corporate proposals; similarly, a large legislative majority is more effective in passing legislation and blocking actions by minority interests. See Crain \& Tollison, supra, at 114 .
} 
tion of governmental powers into judicial, executive, and legislative branches raises, rather than lowers, the cost of interest group legislation. The traditional model seems more plausible than the view currently held by leading public choice theorists that the separation of powers is simply a subterfuge masking a collusion among the various branches of government, thereby facilitating wealth transfers from the public at large to discrete, well-organized special interests.

Thus, those constitutional drafters interested in designing a governmental structure to impede rent-seeking will rely on the separation of powers as an integral part of their constitutional system. All structural impediments to rent-seeking, however, are not the same. Legislatures, for example, may be bicameral or unicameral, and the other branches of government may display varying degrees of independence. The remainder of this Section will explore these and other more subtle aspects of a constitutional system of checks and balances.

Wealth transfers to successful interest groups are inexorably linked to the costs of obtaining such transfers. As the costs go up, the level of transfer activity declines. An obvious example concerns legislative size: as the size of the legislature goes up, it becomes less expensive for the losers in the wealth transfer process to affect political outcomes. ${ }^{86}$ When the size of the legislature increases, interest groups find that their influence (at any given level of expenditures) correspondingly declines. ${ }^{87}$ Thus, constitutional drafters

${ }^{88}$ R. McCormick \& R. Tollison, supra note 8, at 34 .

${ }^{87}$ For several reasons, legislative size plays an important role in determining the ultimate level of rent-seeking activity.

First, increasing legislative size increases the number of vote suppliers and reduces the costs of influence or votes. Since in [the economic theory of legislation] . . . politicians are brokers between winners and losers in the wealth-transfer process, the degree of competition in the legislative process will affect their brokerage fee. . . . [I]ncreases in house size will reduce the price of influence because of reduced monopoly power among suppliers . . . . Second, there is a perhaps more important effect of legislative size due to the fact that larger legislatures mean smaller relative influence for any individual legislator. . . . Larger legislatures are thus characterized by relatively weak individual legislators, weak in the sense that the influence of any one of them is likely to have a small impact on the income of a lobbying group. The third reason . . . is that a larger legislature reduces the number of voters per legislator, and this might lead to improved policing by voters. Another way of saying the same thing is to argue that larger legislatures will more closely represent the entire citizenry, and 
interested in designing a constitutional system to reduce the incidence of interest group transfer activity will construct a large legislature. Of course, marginal conditions still hold, and at some point the gains to society of reducing interest group activity will equal the costs of maintaining a huge legislature. ${ }^{88}$ At this point, society will have achieved the "optimal" amount of rent-seeking.

Another way to bolster the efficacy of a separation of powers is to require that various elected officials appeal to different constituencies for political support. ${ }^{89}$ For example, the nature of the underlying transaction costs may be such that the representative of a particular subdivision is easily influenced by a particular interest group to support a particular statute. If influencing this legislator is all the interest group has to do to prevail, the costs of interest group influence will be very low. If, however, an interest group must put together a large number of coalitions representing different constituencies to influence political outcomes, the cost of obtaining such influence will increase. So, for example, where a government is structured so that the executive is elected from one set (or subset) of voters, and legislators from a different set (or sets in the case of a bicameral legislature), and judges from a third set, the cost of influencing political outcomes will likely prove higher.

It is easy to see why this is so if we observe the interest group's activities from the perspective of a single, political-support-maximizing regulator. This regulator may find that supporting a wealth

hence there will be a smaller level of wealth transfers supplied under these circumstances.

Id. at 33-34 (citation omitted).

${ }^{88}$ See id. at 13 n.9 ("Even though there is variation in legislative sizes, there is a remarkably small band within which legislative sizes seem to fall. This follows quite easily from the fact tbat transactions costs increase significantly as size increases in any group arrangement, such as a legislature."). This theoretical and empirical result was anticipated by James Madison. As Madison observed in The Federalist No. 10: "[H] may be the representatives must be raised to a certain number in order to guard against the cabals of a few; and that however large it may be they must be limited to a certain number in order to guard against the confusion of a multitude." The Federalist No. 10, at 82 (J. Madison) (C. Rossiter ed. 1961). He wrote in the Federalist No. 58:

The people can never err more than in supposing that by inultiplying their representatives beyond a certain limit they strengthen the barrier against the government of a few. Experience will forever admonish them that, on the contrary, after securing $a$ sufficient number for the purposes of safety, of local information, and of diffusive sympathy with the whole society, they will counteract their own views by every addition to their representatives.

The Federalist No. 58, at 360 (J. Madison) (C. Rossiter ed. 1961).

${ }^{89}$ J. Buchanan \& G. Tullock, supra note 3 , at 233-48. 
transfer to a particular group is clearly to his political advantage. A good example is the consistent support for tobacco subsidies from senators from North Carolina. If the approval of these senators was the only action required to sustain such subsidies, the subsidies might be even larger than they are at present. The requirement that the senators from North Carolina must obtain a majority vote of both houses of Congress (whose members come from a wide variety of constituencies, most of which do not benefit from such subsidies) and must avoid having their statute vetoed or declared unconstitutional, substantially raises the cost of obtaining such transfers. ${ }^{90}$

For related reasons, having a bicameral legislature with significant differences in the size of the two houses also raises the price to interest groups of obtaining favorable legislation. ${ }^{91}$ As Mancur Olson has shown, the cost of making collective decisions goes up in a nonlinear faslion-the costs increase at a faster rate than the growtl in the size of the legislature. ${ }^{92}$ As a result, if the total size of the legislature is held constant, increasing the size of one louse (with a concomitant decrease in the size of the other house) raises tle cost to an interest group of obtaining agreement in that house by an amount that is greater than the group's savings in the other house. ${ }^{93}$

${ }^{\circ}$ Indeed, only the logrolling ability of tbe senators from North Carolina and other tobacco states enables such legislation to be passed at all.

${ }^{\text {} 1 ~ I n ~ a d d i t i o n, ~ h a v i n g ~ a ~ b i c a m e r a l ~ l e g i s l a t u r e ~ i s ~ a ~ l o w-c o s t ~ d e v i c e ~ f o r ~ i m p l e m e n t i n g ~ a ~ s y s-~}$ tem of diverse representation that, as described above, serves to reduce the incidence of special interest legislation. As James Buchanan and Gordon Tullock have observed:

[I] $f$ the basis of representation can be made significantly different in the two houses, the institution of the bicameral legislature may prove to be an effective means of securing a substantial reduction in the expected external costs of collective action without incurring as much added decision-making costs as a more inclusive rule would involve in a single house.

J. Buchanan \& G. Tullock, supra note 3, at 236.

${ }_{92} \mathrm{M}$. Olson, supra note 59 , at 53-65.

${ }^{83}$ See R. McCormick \& R. Tollison, supra note 8 , at 44 . Begin with the assumption of a bicameral legislature consisting of a house and a senate. If there are 200 legislators equally divided between the two houses, then an interest group must provide sufficient political support to 51 people in each body to gain passage of a statute. Assume also that the statute is not vetoed or subsequently declared to be unconstitutional. If the structure of government is altered so that the senate has 40 members and the house has 160 , the "logic of collective action" dictates that the cost to the interest group of obtaining passage of its statute will go up, because the increase in the cost of influencing the outcome in the house will be greater than the decrease in the cost of influencing the outcome in the senate. In 
These structural mechanisms may appear to be a rather circuitous means to accomplish the constitutional goal of decreasing interest group dominance. After all, “a shield of 'rights'-spheres of individual autonomy into which government may not enter" seems a more direct method to protect against the pernicious wealth-transferring activity of organized interest groups. Guaranties against invasions of privacy, impairment of private contractual obligations, takings of private property, denial of equal protection under the law, and discrimination against certain citizens by others are all obvious candidates for inclusion in a constitution that tries, by constitutional fiat, to protect society against the danger of interest group domination of the political process. ${ }^{95}$

The problem with these constitutional directives, however, is that, as compared to structural constitutional rules, they are likely to be less effective as a means of controlling post-constitutional interest group opportunism. First, unlike structural constitutional rules, constitutional directives that forbid government officials from doing certain things (such as interfering with private contractual relationships) are not self-executing. Rather, such directives rely on an allegiance to vague constitutional principles and on the exercise of self-restraint by the very self-interested officials the directives are desigued to control. These rules therefore carry with them the risk that they will be ignored when it is convenient for officials to do so.

Second, constitutional directives require interpretation and therefore are subject to manipulation by interest groups and politicians. Much of the scholarship of Professor Richard Epstein, who clearly recognizes that the goal of a constitution is to control interest group behavior, illustrates this point. Professor Epstein presents a plausible argument that administrative agencies are "flatly unconstitutional." $\mathrm{He}$ also persuasively argues that the

other words, the cost of making collective decisions will, with the shift in the two houses' sizes, increase in a nonlinear fashion-i.e., it will increase at an increasing rate. See M. OIson, supra note 59 , at 53-65.

or Sunstein, Interest Groups in American Public Law, 38 Stan. L. Rev. 29, 33 (1985).

os See Sunstein, Naked Preferences and the Constitution, 84 Colum. L. Rev. 1689, 168991 (1984). Sunstein describes such constitutional provisions as "united by a common theme and focused on a single underlying evil: the distribution of resources or opportunities to one group rather than another solely on the ground that those favored have exercised the raw political power to obtain what they want." Id. at 1689.

${ }^{98}$ Epstein, Self-Interest and the Constitution, 37 J. Legal Educ. 153, 156 (1987). 
constitutional principle of substantive due process, ${ }^{97}$ the constitutional prohibition against takings of private property without just compensation, ${ }^{98}$ and the constitutional prohibition against impairment of contractual obligations ${ }^{99}$ might be extremely important constitutional bulwarks against interest group malfeasance; but, as he himself observes, many of these safeguards have long been ignored.

Such decidedly normative views of constitutional language, even assuming that they are correct, demonstrate the malleability of such directives in the face of interest group pressures and changing circumstances. ${ }^{100}$ In the face of decisionmakers' ability to devise creative interpretations of text, it is a weak constitution that relies on lawyers and constitutional historians to restrain the wealthtransferring activities of interest groups merely by pointing to constitutional language and saying, "See, the Constitution says you must do this or refrain from doing that."

This Section has examined two primary strategies for controlling interest group activity. The first, providing incentives for government officials to behave in public-regarding ways, is not a particularly hopeful approach because of the lack of an observable measure of reward or punishment. The only successful means to provide incentives is to structure a system of competition among providers of governmental services and to permit citizens to choose freely among them.

The second strategy for controlling interest group activity is to raise the costs to interest groups of influencing political outcomes; this strategy can be divided into two components. The first component consists of structuring the organization of government so as to raise the costs to interest groups of obtaining favorable decisions from the government. This method of constitutional design appears to hold significant promise as a means of controlling interest

97 Id. at 158.

ss R. Epstein, Takings: Private Property and the Power of Eminent Domain 7-31 (1985).

${ }^{99}$ Epstein, Toward a Revitalization of the Contract Clause, 51 U. Chi. L. Rev. 703, 714-15 (1984).

${ }^{100}$ An excellent demonstration of the point is contained in Professor Epstein's description of the interest group dynamics underlying New York's maximum-hour legislation that led to the Supreme Court's opinion in Lochner v. New York, 198 U.S. 45 (1905), which held such legislation unconstitutional. Epstein demonstrates that the statute represented the successful attempt by certain interest groups to impose disproportionate burdens upon rival firms by disrupting their ways of doing business. See Epstein, supra note 99, at 732-34. 
group activity. The second component involves drafting constitutional directives and prohibitions that protect the interests of the general public by directing lawmakers to respect individual rights. Rules of this type do not hold much promise as a means of restricting post-constitutional interest group behavior, because they require enforcement by political officials during times of normal politics. This, in essence, is tantamount to relying on the fox to guard the henhouse.

\section{B. Applying the Model: Determining the Optimal Level of Rent-Seeking Within a Society}

The exercise of raw political power to obtain legislation that benefits the politically powerful at the expense of the politically weak is "an underlying evil"101 that a well-functioning constitutional system should be designed to correct. The same economic incentives that lead to the wealth-transferring activities of interest groups in day-to-day political life are likely to lead such groups to attempt to design a constitutional scheme that increases societal wealth by reducing the incidence of such transfers.

If, however, interest group wealth transfers are bad, why do welldrafted constitutions not eliminate the evil completely, rather than merely mitigating it? The answer is simple: it is not costless for a society to eliminate interest group wealth transfers, and the cost of eliminating such transfers will determine the optimal level of transfer activity within a society. Curtailing wealth-reducing activity by interest groups is efficient only up to the point at which the gains from such a reduction equal the costs of attaining the reduction.

One cost of reducing wealth transfer activities is the cost of government itself. ${ }^{102}$ As the discussion of the value of a separation of

\footnotetext{
101 See Sunstein, supra note 95, at 1689.
}

102 The way to eliminate completely the burden of wealth transfer activity is to eliminate the government itself. The discussion in the text makes the assumption that by taking an economic approach to the Constitution, the benefits of government can be made to outweigh the costs. The benefits of government include solving collective action and free-rider problems, as well as providing public goods such as national defense. This discussion is not meant to suggest that in all cases the benefits of goverument outweigh the costs. Indeed, the whole point of the economic theory of legislation is that the costs and benefits of government do not fall evenly among the populace. Well-organized interest groups enjoy a disproportionate share of the benefits, and poorly organized individuals and groups bear a dispro- 
powers indicated, by estabhshing a large bicameral legislature, a constitution can raise the cost to interest groups of effecting pernicious wealth transfers. ${ }^{103}$ This analysis remains valid until it is applied to the limiting case at which all voters are in the legislature. ${ }^{104}$ At some point, however, the incremental, marginal costs of further enlarging the legislature will outweigh the marginal reduction in rent-seeking. ${ }^{105}$

Another valuable mechanism for controlling rent-seeking is to devise a constitutional structure that provides competition among jurisdictions. Individuals benefit under such a scheme because the interjurisdictional competition deters officials from pursuing policies that do not maximize aggregate preferences. ${ }^{106}$ The maintenance of such rival governments, again, is obviously not a costless endeavor, and local governments will still exercise some monopoly power over their constituents for two reasons. First, the efficacy of jurisdictional competition depends on the ability of constituents to "vote with their feet" by leaving jurisdictions with inefficient (or oppressive) local governments. Exercising the right to leave a particular jurisdiction is not costless, however. The most obvious cost is the actual cost of relocation, but other, more subtle burdens also are likely to be quite large. For example, the burden to individual citizens of discovering the costs being imposed by their local government and comparing them with the costs being imposed by rival jurisdictions may be significant. This involves more than simply observing the tax and regulatory burdens imposed in rival jurisdictions; it also involves assessing the benefits offered by the

portionate share of the costs. As usual, at the margins the analysis is difficult, and at the limits it is easy.

${ }^{103}$ See supra notes $91-93$ and accompanying text.

104 See R. McCormick \& R. Tollison, supra note 8, at 34 .

${ }_{10}$ In fact, even in a political referendum-i.e., near-perfect democratic participation-interest groups still will exert a disproportionate influence on voting outcomes. See Schneider \& Naumann, Interest Groups in Democracies-How Influential Are They? An Empirical Examination for Switzerland, 38 Pub. Choice 281, 293 (1982). Groups will have more control over the agenda and more control over the dispersion of information about the subject of the referendum because of the familiar free-rider problems facing the other voters.

${ }^{108}$ See Epple \& Zelenitz, The Implications of Competition Among Jurisdictions: Does Tiebout Need Politics?, 89 J. Pol. Econ. 1197, 1198 (1981); Tiebout, A Pure Theory of Local Expenditures, 64 J. Pol. Econ. 416, 418-20 (1956). 
governmental services and entitlements in the various jurisdictions, which is exceedingly difficult to do. ${ }^{107}$

An additional cost of jurisdictional competition is that it provides a disincentive for private individuals and firms to make location-specific capital investments for fear that these investments will be appropriated by the local government. ${ }^{108}$ In addition, as Dennis Epple and Allan Zelenitz have noted, because land is not mobile, local governments subject to jurisdictional competition can still usurp some land rents for their own ends. ${ }^{109}$ As a consequence, increased competition among jurisdictions cannot eliminate completely the ability of local governments to effect wealth transfers. Thus, the traditional argument that jurisdictional competition leads to the efficient production of public goods appears to be overstated. ${ }^{110}$ Jurisdictional competition, as well as organizational structure, is not a panacea; it is an efficient check on interest group activities only up to the point at which its benefits are equal to its costs.

Error costs due to the difficulty of distinguishing rent-seeking from selfless behavior provide another reason why interest group

${ }^{107}$ Seen in this perspective, the presence of jurisdictional competition seems to permit easy identification of the groups likely to he exploited by regulation. Those groups less ahle to migrate among particular jurisdictions will be subject to more exploitation than other groups. See North, supra note 34, at 252 ("The state attempts to act like a discriminating monopolist, separating each group of constituents and devising property rights for each so as to maximize state revenue. . . . The degree of monopoly power of the ruler therefore is a function of the closeness of suhstitute for the various groups of constituents."). Some empirical evidence appears to support this hypothesis. See Cebula \& Avery, The Tiebout Hypothesis in the United States: An Analysis of Black Consumer Voters, 1970-75, 41 Pub. Choice 307, 307-08 (1983).

${ }^{108} \mathrm{Cf}$. McChesney, supra note 26 , at 108 (discussing expropriation by politicians as a general disincentive to investment).

${ }^{109}$ See Epple \& Zelenitz, supra note 106, at 1216. The Epple and Zelenitz analysis assumes that jurisdictional competition takes place along fixed boundaries, so that a firm or individual must physically leave one jurisdiction to avoid the regulations of that jurisdiction. Id. Though this assumption generally is true, it may not hold in every context. Corporations, for example, may incorporate in jurisdictions witl which they have no physical nexus. Some commentators helieve that this ability provides significant incentives for state governments to develop laws of incorporation that benefit shareholders. See Winter, supra note 56, at 289. Even under these conditions, however, significant incentives exist for local interest groups and governments to engage in inefficient wealth transfer activity. See Macey \& Miller, Toward an Interest-Group Theory of Delaware Corporate Law, 65 Tex. L. Rev. 469, 499-509 (1987).

${ }^{110}$ See Epple \& Zelenitz, supra note 106, at 1216; see also Tiebout, supra note 106, at 424 (making the original argument that competition would lead to efficient production of public goods). 
manipulation of the pohtical process cannot be eliminated completely. Merely because interest groups agitate in favor of a particular law or policy does not mean that the law or policy would not serve some legitimate end of government. Merely because certain interest groups supported the Civil Rights Act of 1964, for example, does not mean that the statute serves only narrow private interests. ${ }^{111}$ The better argument is that the statute, by making certain types of race-based economic discrimination illegal, opened markets and thereby created a public good by reducing the incidence of prior discrimination that clearly benefited certain groups at the expense of others. ${ }^{112}$

Similarly, the progressive income tax has been viewed both as a statute driven by interest group pressures, designed to transfer wealth from the disorganized rich to other, more politically powerful groups, ${ }^{113}$ and as a means of maximizing social utility. ${ }^{114}$ Rather than being an example of rent-seeking, it is argued, the progressive income tax scheme may serve the public interest by eliminating free-rider problems that "might thwart private efforts to bring about the level of transfers from rich to poor that the rich would prefer."115 In contrast, environmental protection statutes, which appear to be classic public interest statutes designed to ensure the optimal production of a public good (i.e., a clean environment), often contain features consistent only with the protection of special interests. ${ }^{116}$

11 See W. Eskridge \& P. Frickey, Cases and Materials on Legislation: Statutes and the Creation of Public Policy 4-28 (1987) (detailing the passage of the Civil Rights Act in Congress).

${ }^{112}$ Indeed, racial discrimination can itself he viewed as a form of interest group activity. Discrimination against blacks increases the demand for the lahor of certain groups of white workers and simultaneously keeps the prices of certain products artificially low by retarding demand. The consumers of those products, along with those who compete with blacks in the workplace, are the true beneficiaries of racial discrimination. For similar examples of discrimination on economic grounds, one need only look to the confiscation of the property of Japanese-Americans, see, e.g., Korematsu v. United States, 323 U.S. 214 (1944), or to the current efforts by American labor unions to ban aliens from the work force, see, e.g., SureTan, Inc. v. NLRB, 467 U.S. 883 (1984).

113 See M. Friedman, Capitalism and Freedom 161-76 (1982).

114 See Posner, supra note 7, at 270-71; see also A. Lerner, The Economics of Control 23840 (1944) (arguing that a progressive tax does not discourage risky investments).

11 Posner, supra note 7, at 265.

${ }^{116}$ See Pashigian, The Effect of Environmental Regulation on Optimal Plant Size and Factor Shares, 27 J.L. \& Econ. 1 (1984) (showing how certain regulations, ostensibly desigued to protect the environment, reduce competition and benefit larger industries by imposing a disproportionate burden on small manufacturing firms). 
Furthermore, as Judge Frank Easterbrook has observed, most statutes represent a mix of public interest principles and interest group compromises. ${ }^{117}$ The fact that such statutes serve dual purposes makes distinguishing between the private interest provisions and the public-regarding ones even more difficult. Relying on individuals (such as judges) to distinguish between the public and the private interests does not provide any assurance that majoritarian interests will be served by governmental action.

The structural devices designed to raise the costs of interest group bargains ${ }^{118}$ increase the costs of passing laws generally and therefore raise the costs of all legislation. As a consequence, these devices will impede the passage of some laws designed to serve the public interest, as well as some laws designed to effect interest group bargains. The opportunity cost to society of not having these public interest measures enacted into law must be counted as one of the costs of devising a system of checks and balances designed to reduce rent-seeking.

Even assuming that constitutional drafters act with the best intentions and on the basis of perfect information, all of these arguments point to the conclusion that the optimal level of rentseeking in society will be greater than zero. A constitution can only alter the political equilibrium to bring it closer to the point at which rent-seeking becomes a positive sum game; a constitution cannot-and ought not-completely ehminate such rent-seeking.

\section{Evaluating the United States Constitution}

The dominant view among public choice theorists is that the United States Constitution facilitates the political equilibrium among interest groups and does not alter the interest group process, except perhaps to facilitate it. ${ }^{118}$ As should be clear from the preceding discussion, however, that analysis ignores a number of structural features of the Constitution that appear specifically designed to combat the problem of wealth transfers by interest groups. The Constitution employs a bicameral legislature, with houses of widely different sizes. The American constitutional sys-

\footnotetext{
11 Easterbrook, supra note 9, at 17.

11 See supra notes 68-93 and accompanying text.

119 See Tollison, supra note 19, at 55-59.
} 
tem also institutes a regime of checks and balances by creating both a federal judiciary that is insulated from political pressure because its judges have life tenure and salaries that cannot be reduced, and a federal executive with authority to veto acts of Congress. In addition, each of the three branches of government must appeal to different constituencies for political support, thereby further reducing the power of interest groups to affect political outcomes. Finally, the Constitution envisions a federal form of organization in which citizens are free to travel among the several states, thereby reducing the incentives of individual states to engage in transfer activities.

Each of these features of the Constitution provides independent support for the hypothesis that the Constitution was designed to impede rather than to facilitate rent-seeking. These provisions also provide support for the hypothesis that a constitution, by its very structure, establishes the political equilibrium within a polity by fixing the level of transaction costs faced by interest groups that attempt to obtain favorable legislation. By employing features that raise the transaction costs of interest groups, the Constitution decreases the incidence of such activity.

Having said this, the question remains whether the Constitution fixes the transaction costs facing interest groups at the optimal level. If it does, then reducing the incidence of negative-sum interest group activity in society would cost more than it is worth. Unfortunately, there are indications that this is not the case and that some inefficient wealth transfers could be avoided, at a net gain, under a revised constitutional regime. ${ }^{120}$ Potential improvements to the existing constitutional regime can be divided into two categories. First, adjustments could be made in the current system to make it constrain rent-seeking as was originally intended by the framers. Second, new provisions could be added to the current system to take account of changed circumstances.

It must be emphasized at the outset that the constitutional revisions suggested here do not necessarily reflect mistakes in the current system. The framers drafted the Constitution in a very differ-

120 The discussion tbat follows is not meant to imply tbat the Constitution ought to be amended. The amendment process has its own perils, and the likelihood is great that interest group pressures could take hold of the amendment process to produce a constitutional framework inferior to the present one. 
ent environment from the one in which we live today. Technological advancements have altered the complexion of interest group politics: national political campaigns now are conducted via television and direct mail; computers greatly facilitate the identification of individuals and groups affected by an interest group's activities; and modern means of communication facilitate interest group interaction and interest group access to the political process. All of these relatively recent developments lower the transaction costs that face interest groups attempting to organize and effect wealth transfers. These developments have led to a huge proliferation in the number of interest groups, as well as to the refinement of the goals of such groups. In other words, more interest groups exist now than ever before, both in absolute numbers and in relation to the size of the population, and the goals of these groups are focused more discretely than previously. These developments make constitutional control of interest group activities more difficult.

\section{A. Adjustments to the Current System}

The existing constitutional regime describes the organization of government and the separation of powers in exceedingly broad, and often ambiguous, terms. The Constitution, for example, vests legislative power in a Senate and a House of Representatives, ${ }^{121}$ but does not stipulate any of the details concerning the day-to-day lawmaking procedures to be used within these legislative bodies. A basic tenet of public choice theory, however, is that specification of such details (e.g., voting procedures ${ }^{122}$ ) can have a significant impact on political outcomes.

The Constitution leaves to the House and Senate the details of their voting procedures. Once legislation is proposed, because of the bicameral nature of the Congress, approval by what is, in effect, a supermajority of the legislators is required to pass the statute. ${ }^{123}$ Thus, to some extent article I establishes a decisional pro-

121 U.S. Const. art. I, § 1.

122 The seminal work, of course, is Kenneth Arrow's Social Choice and Individual Values (2d ed. 1963). For an excellent review of Arrow's original work, as well as a relatively accessible discussion of the postulates and proof of Arrow's theorem, see D. Mueller, supra note 64, at 185-88; see also Levine \& Plott, Agenda Influence and Its Implications, 63 Va. L. Rev. 561 (1977) (demonstrating the importance of agenda control and suggesting possible applications of public choice theory to judicial decisionmaking).

${ }^{123}$ J. Bucbanan \& G. Tullock, supra note 3, at 232-48; see supra notes $89-93$ and accompanying text (discussing the effect of bicameralism on interest group influence). 
cess that, by forestalling cyclical majorities, can yield coherent and consistent legislative choices. ${ }^{124}$

The procedures for considering proposed bills, however, are much different today than they were during the period immediately following the ratification of the Constitution. In the early days, "bills were considered and approved in principle by the Committee of the Whole before they were sent to a select committee to be put into legislative language."128 As a consequence, anyone who wanted to propose a statute had to persuade a majority of the entire legislature that the statute was worth pursuing, because deliberation by the entire body preceded markup by the specialists. ${ }^{126}$

Today, of course, bills generally are reported out of committee first and voted on by the House or Senate only after being discussed at the committee level. This process makes enacting statutes easier, thus helping to ensure the passage of fringe statutes that could not previously have obtained sufficient support or even have made it onto the legislative agenda. In addition, the current system facilitates logrolling, as committee members can easily take part in political trading among themselves, thus ensuring that bills reported out of committee have broad-based, bipartisan support, if only because of the nature of the compromises reached at the committee level. Finally, the current system facilitates interest group politics by making it cheaper for the interest groups affected by a particular piece of legislation to identify ex ante the relevant legislators to target regarding that legislation. By targeting their lobbying efforts towards the members of the relevant committee, these interest groups can economize greatly on lobbying costs.

Thus, specifying the structure of the deliberative process within the branches of the legislature could improve the operation of government by further raising the costs to interest groups of obtaining passage of legislation. Requiring consideration and approval of statutes by a "Committee of the Whole" before sending them to select committees would be a step in this direction.

124 See Mayton, The Possibilities of Collective Choice: Arrow's Theorem, Article I, and the Delegation of Legislative Power to Administrative Agencies, 1986 Duke L.J. 948, 956.

125 Malbin, supra note 50 , at 95.

128 Id. at 95-96. 


\section{B. A New Suggestion}

Perhaps the greatest departure from the system of government envisioned by the framers is the open-ended delegation of legislative power to administrative agencies that began with the New Deal and continues to this day. This delegation of lawmaking power to administrative agencies bypasses the deliberative process of our tripartite system of government and thereby facilitates the ability of interest groups to obtain their desired ends by "capturing" the very administrative agency designed to regulate them. Interest group capture of administrative agencies, however, is unusual. Agencies normally are created amid controversy and conflict among competing interest groups, when legislators are uncertain about the political costs and benefits of pursuing alternative courses of action. In such circumstances, the optimal political decision for legislators is to delegate lawmaking or regulatory authority to an administrative agency. ${ }^{127}$

In other words, as Peter Aranson, Ernest Gellhorn, and Glen Robinson have observed, the ability to delegate broad lawmaking power to administrative agencies often creates a "regulatory lottery"128 that simply relegates important policy decisions to the highest interest group bidder and permits individual legislators to avoid accountability for the consequences:

Legislators delegate authority [to administrative agencies] in order to reduce various costs of legislating, which allows them to legislate more private goods. Stated differently, delegation [of regulatory authority, legislative authority, or both,] reduces the legislator's marginal cost of private-goods production, which, ceteris paribus, yields more legislation and more public-sector private-goods production. ${ }^{128}$

Though one can argue, as Professor Epstein and others have done, that such broad delegations are unconstitutional, ${ }^{130}$ making such an argument does not change the fact that such delegations

\footnotetext{
${ }^{127}$ See Aranson, Gellhorn \& Robinson, A Theory of Legislative Delegation, 68 Cornell L. Rev. 1, 58-60 (1982); see also Fiorina, Legislative Choice of Regulatory Forms: Legal Process or Administrative Process?, 39 Pub. Choice 33, 56-57 (1982) (applying Kenneth Shepsle's analysis of risky electoral choices to the regulatory problem).

${ }^{128}$ Aranson, Gellhorn \& Robinson, supra note 127, at 60-61.

128 Id. at 56.

${ }^{130}$ See Epstein, supra note 96, at 156; Mayton, supra note 124, at 964-65.
} 
have been taking place without successful challenge for more than fifty years, despite the fact that agencies created under such broad delegations have often failed to serve the public interest. ${ }^{131}$ The very existence of such agencies is a glaring contradiction of the carefully constructed lawmaking procedures articulated in article I, which involve "the House, the Senate, and the presidency as three separate members of a grand legislative committee."132 In hight of this contradiction, it is highly unlikely that the framers would have permitted the lawmaking procedures of article I to coexist with the current system, under which administrative agencies are given extremely broad lawmaking authority. Thus, in addition to the revisions in the committee system, ${ }^{133}$ the abolition of delegations of legislative authority to administrative agencies would prevent the carefully constructed article I process from being subverted by politicians seeking merely to maximize their own political support. ${ }^{134}$

Another unanticipated post-constitutional event has been the broad construction of the commerce clause by the federal courts.

${ }^{131}$ The Civil Aeronautics Board, the Federal Communications Commission, the Federal Trade Commission (FTC), and the Occupational Safety and Health Administration (OSHA) are examples of agencies created with open-ended delegations of administrative authority. See Mayton, supra note 124, at 963 . For a thorough study of the failure of agencies with broad delegations of authority to develop effective pohicies that serve the public interest, see T. Lowi, supra note 64; see also Nichols \& Zeckhauser, Government Comes to the Workplace: An Assessment of OSHA, 49 Pub. Interest 39, 42 (1977) (showing how OSHA has imposed costs on businesses without any improvement in the incidence of work-related injuries and illnesses); Posner, The Federal Trade Commission, 37 U. Chi. L. Rev. 47 (1969) (describing the negative impact of the policies of the FTC). But cf. Kelman, On DemocracyBashing: A Skeptical Look at the Theoretical and "Empirical" Practice of the Public Choice Movement, 74 Va. L. Rev. 199, 235-68 (sharply criticizing public choice analyses of regulatory agencies' performances).

132 Mayton, supra note 124, at 954 . These three institutions represent different constituencies with different preferences; this diversity of interests and goals raises the costs of obtaining special interest legislation. From the perspective of Mayton's "grand legislative committee," article I establishes a unanimity rule among these three bodies for passage of a statute; each has veto power over any law that it opposes. See id. at $954 \mathrm{n} .22$.

${ }^{133}$ See supra notes $125-26$ and accompanying text.

134 A constitutional prohibition on delegations would not be costless. Mayton and others have argued that the administrative agencies, created by Congress after first identifying a defect and then working out the rudiments of a solution in the form of precise guidelines, are successful in providing public benefits to private citizens. See Mayton, supra note 124, at 963 (identifying the Securities Exchange Commission, the Social Security Administration, and the Environmental Protection Agency as agencies held in relatively high regard in terms of their "coherency, stability, and professionalism").

Any gap left by the elimination of administrative agencies would somehow have to be filled. One possibility is that the states could play a greater role in the process of social ordering than they do now. This would likely be an improvement over the present system. 
As Richard Epstein has argued, the benefits of federalism in the constitutional system have been undercut significantly by the massive expansion of federal power under the commerce clause. ${ }^{135} \mathrm{Ba}$ sically, his argument posits that the increase in the federal government's authority to regulate interstate commerce has resulted in a usurpation by the federal government of many of the powers traditionally relegated to states and thereby has decreased the efficacy of the federal system.

The expansion of the federal government through the creative use of the commerce clause also has decreased the cost to interest groups of achieving wealth transfers through the political process. Under a constitutional system of truly limited national powers, to obtain passage of a statute with a national impact, interest groups have to obtain the support of fifty state governments (most of which have bicameral legislatures and state executives with veto power over legislative enactments). The ability of citizens to move freely among the states provides a strong incentive for states to refrain from passing laws that impose undue costs on certain subgroups of citizens. ${ }^{136}$ In contrast, under a constitutional system of preeminent federal powers, to obtain passage of a statute with like national impact, interest groups only have to obtain the support of the national legislature or perhaps of an administrative agency within the national government. Thus, the abolition of administrative agencies would force the return of a large element of decisionmaking authority back to the states, and would do so without the need to rely on the good intentions of federal judges and legislators.

\section{Conclusion}

It is axiomatic that voluntary transactions in the private sector provide all parties to such trades with a net welfare gain. Otherwise, the transactions would not occur. The occurrence of such transactions also provides a net gain to the public at large as entrepreneurs are forced by competitive pressures to provide high-quality goods and services at low prices.

\footnotetext{
135 See Epstein, The Proper Scope of the Commerce Clause, 73 Va. L. Rev. 1387 (1987); Epstein, supra note 96, at 156.

${ }^{136}$ See supra notes $34-37$ and accompanying text.
} 
By contrast, the welfare implications of transactions that occur because the legislature mandates them are indeterminate. Some may provide net improvements in the social welfare; others clearly do not. Often such transactions merely reflect the triumph of raw political power over the disorganized public at large.

In any advanced society, persons in search of profit must decide whether to allocate their efforts to the private sector, where they pursue a strategy of wealth creation through trading, or to the public sector, where they (for good or ill) pursue a strategy of wealth transfer through rent-seeking. The latter strategy provides counter-incentives to wealth creation and eventually will sap a nation of its wealth. The core function of a well-ordered constitutional regime is to restrain such wealth transfers and guide transactions to the private sphere.

There are two ways to attain this goal. The first strategy is to offer public officials adequate incentives to refrain from succumbing to the rent-seeking activities of organized interest groups. This strategy is modeled on the primary tactic used by shareholders in public corporations to induce officers and directors to act in the best interests of the shareholders. Unfortunately, due to the lack of any pricing mechanism in the public sector that is analogous to the market for shares of public corporations, this strategy cannot easily be transferred to the realm of constitutional economics.

The second strategy holds more promise. Under this alternative, the governmental structure created by the Constitution is viewed as a means of raising transaction costs to interest groups intent on pursuing a policy of rent-seeking. These increased costs lower the incidence of redistributive wealth transfers to the politically powerful and, at the margin, guide profit seekers back to the private sector.

The constitutional strategy of raising transaction costs manifests itself in two ways. The first is through language, textual admonitions to those in government not to shift costs to the politically weak. This strategy, however, is likely to prove ineffective over time. American constitutional history is a testament to the proposition that the language of constitutional directives, such as those contained in the contract clause, the commerce clause, and the takings clause, is almost infinitely malleable. As a result, con- 
stitutional directives do not hold much promise as effective constraints on rent-seeking behavior.

Alternatively, constitutions can seek to constrain rent-seekers by creating institutional structures that effectively raise the transaction costs of organized interest group activity. It is this strategy that holds real promise for establishing a successful constitutional order. Structural features such as the executive veto, the independent judiciary, and the bicameral legislature (with differentiated house sizes) are best seen as structural devices that raise the costs of rent-seeking. The conventional wisdom among public choice theorists disputes the conclusion that such structural features raise the costs of interest groups' efforts to bring about wealth transfers. Indeed, the conventional wisdom is that these features facilitate rent-seeking by lowering rather than raising the costs of interest group activities. But these theorists fail to understand the operation of these structural features. In addition, they fail to recognize that the incentives leading interest groups to seek wealth transfers during times of ordinary politics also lead interest groups to seek to block such transactions during times of constitutional creation.

An examination of the United States Constitution provides support for the proposition that constitutions can be public-regarding, even when the legislation generated under the subsequent constitutional regime is not. The Constitution, in addition to providing a farrago of admonitory constraints on government's acquiescence to interest group demands, erects a number of structural devices that are more effective at raising the transaction costs of interest group activity.

The Constitution, however, does not appear to restrain sufficiently the passage of special interest legislation. First, legislators who want to avoid controversial or indeterminate decisions as to which interest groups to favor can forfeit vast amounts of discretion (and thus responsibility and accountability) to administrative agencies, which function outside of the tripartite legislative process envisioned by our constitutional structure. The modern administrative agency lowers the cost to interest groups of influencing the political process; it conflicts in the most fundamental way imaginable with the core constitutional function of raising the transaction costs to interest groups of obtaining passage of favored legislation. The administrative agency is an invention of political entrepreneurs never envisioned by the framers. 
Second, modern technological developments have lowered transaction costs for special interest groups. Such groups are more numerous and exert more direct pohtical pressure than ever before. The Constitution was designed to constrain a cruder form of interest group activity at a time when the natural impediments to interest group formation-in the form of information and communication costs-were much higher than they are today. As a consequence, altering certain aspects of the deliberative process within Congress to raise the costs to interest groups of influencing legislative outcomes is a wise course of action. Requiring consideration and approval of statutes by a "Committee of the Whole" before sending them to select committees is an example of such a structural improvement.

It seems appropriate, however, to end on a note of caution. As this Article has attempted to show, the incentives facing lawmakers (and private citizens) during times of constitutional creation are fundamentally different than those at times of ordinary lawmaking. Amendments to the Constitution fall between these two categories. Though the amendment process is a topic worthy of separate treatment, the incentives facing pohtical actors during the amendment process are less hikely to generate public-regarding outcomes than when a new government is being organized on a clean slate, as it was in Philadelphia in 1787. 